\title{
Lecturer's Language Styles in Teaching English as Foreign Language Class of Postgraduate School, State University of Medan
}

\author{
Aini Melbebahwati Saragih \\ English Applied Linguistics \\ Postgraduate School \\ State University of Medan \\ Indonesia \\ mel_pinkaliztha@yahoo.com
}

\author{
Anggraini Thesisia Saragih \\ English Education Department \\ Faculty of Languages and Arts \\ State University of Medan \\ Indonesia \\ anggrainisaragih@yahoo.com
}

\begin{abstract}
The aim of this research was to analyze types of language styles used by an English lecturer of Postgraduate School, State University Medan. It was conducted by using qualitative descriptive design. The data of this research were the utterances of a lecturer of Teaching English as Foreign Language subject of Postgraduate School, State University of Medan, containing some language styles transcribed into the written form of the transcripts of the teaching-learning activity. The sources of data were taken from Teaching English as Foreign Language class for four weeks. The techniques of data collection in this research were analyzing the transcripts of the lecturer's utterances in a classroom setting. The supporting instrument to collect the data was voice recorder. The data were analyzed by using interactive model proposed by Miles, Huberman and Saldana (2014) with three phases of data analysis. The phases are data reduction, data display and conclusion drawing or verification. After analyzing the types of language styles used by the lecturer for four weeks, it was found that only three types of language styles used by the lecturer in teaching-learning activity. They were formal style, consultative style and casual style. The most dominant language style is casual style $(\mathbf{7 7 . 2 7 \%})$, followed by formal style $(11.36 \%)$, and consultative style $(11.36 \%)$ in similar amount of use.
\end{abstract}

Keywords-Interactive Model, Language Styles, Lecture's Language Styles, TEFL Class

\section{INTRODUCTION}

Language is a symbolic system used by communicators to construct and convey information (Findlay, 1998). The use of language in daily life, whether it is in spoken or written way, is influenced by language styles that are different from one another. The styles refers to varieties according to use. The study of language is further complicated by the fact that speakers can adopt different styles of speaking.

Keller and Calhoun (1997) states that language style is a purely human and non-instinctive method of communicating ideas, emotions and desires by means of a system of voluntarily produced symbols. It means that language plays a crucial role and vital role in human life and also has many advantages of various aspects of human life.

As one part of human life, education in its most general significance can be recognized as a specific transaction which may go on between the generations of human beings in which new-comers to the scene are initiated into the world they are to inhabit (Oakeshott, 1971). Specifically, education in its more general understanding of some people, may involve the process of teaching and learning. In this process of transaction, a teacher uses language in transferring knowledge as well as ideas to her students. Therefore, as an evidence that a language used in communicating with students in the classroom, the sense of selecting appropriate styles of language occurs.

Dealing with the effect of the language styles used by teachers in educational field, it is found that teaching requires skill, insight, intelligence and diligence in which the faculty struggle and succeed in a variety of ways to meet the challenges of the classroom (Nelson, 2007). Thus, the application of language styles by the teachers in the classroom can influence the teaching and learning process. As a part of education, teaching and learning may also exist in a higher education as postgraduate level. Relevant to the matter of language style, it is found that a lecture is possible to develop various language styles depending on the situation and her/his character. One instance of language style used by a lecturer was found in Grammatics class of Postgraduate School, State University of Medan as shown in the following:

Situation: Lecturing in the classroom

"Terlalu banyak yang mesti di-discrepancy-kan. So, the outline is such one, then, original idea and its social context. So you can detail. Kalau anda bisa detaikan, oke, tentu berdasarkan grammatics. Alright, I think that's all. You can copy the book." 
It can be inferred from the utterance that the type of language style occurred is formal style. As Joos (1967) states that formal style is a style that is designed to inform, and it is generally where communication is one way communication with little or no feedback from the audiences for examples in speech, public lectures and so on. In lecturing the subject of Grammatics, the lecturer tended to use formal language style as he mentioned the students with the word 'anda' and the pattern of some sentences showing formality in its use as in 'the outline is such one, then, original idea and its social context'.

In regarding to the explanation above, this research aimed to analyze the types of language style used by a lecturer in Teaching English as Foreign Language (TEFL) class of Postgraduate School, State University of Medan.

\section{REVIEW OF LITEARURES}

Chaer (1995: 113) describes that language style is a way to express the idea with special language showing the writer's soul, spirit and concern (the use of vocabulary). A good language must have four elements which are: honesty, respect, good manners and interest. According to Brown (1980: 191), language style ranges from formal style to informal style depending on social context, relationship of participants, social class, sex, age, physical environment and topic of the event. The language style can change based on the social context. Social context encompasses addressee, addresser, topic, time and place.

Moreover, language style varies according to situation whether it is public or private, formal or informal, who is being addressed and who might be able to overhear. Simply, it is clear the use of language depends on the context where people are and with whom they are speaking to (Thomas and Wareing, 1999: 10).

According to Joos (1967: 153-155), there are five categories of language styles which are: frozen, formal, consultative, casual and intimate style. He gives a definition about frozen style as a style which is intended to be remembered and used in a very formal setting such as in palace, church, speech of state ceremony, and some other occasions or in public speaking. This style is also used in documents, institutions, wedding ceremonies and other kinds of historical documents. While formal style is defined as a style that is designed to inform. It is used for important situation and also in addressing audience, particularly when the audience is in big number. Formal style is usually conducted in a very formal speech, public lectures, textbooks, formal letters, wedding ceremonies and so on. It is based on the standard style, and the main characteristics of it are the sentences that should have the patterns, such as subject, predicator, object and compliment.

Then, consultative is a style that shows people's norm for coming to terms with strangers who speak a language but whose personal stock of information may be different. It is used for semiformal situation. Consultative style is one type of language which is required from everyday speaker. Casual style is used for conversation in a relaxed or normal situation that is appropriate to the conversation with our friends or some, such as outside the classroom, when the students have a chat. Generally, casual style is characterized by the use of the first name or even nickname rather than a little name and last name in addressing one another.

In education, language is not only a mean of communication, thoughts and ideas. However, it forges also friendships, cultural ties and as a tool of learning. In relation to this, there are two aspects of language which are inherent in education, namely the function and creativity. The students need language because language and its functions fulfill their needs. Language has function to represent, exchange and organize people's experience as members of society. In conclusion, language is the key of acquiring knowledge and skills. Students are able to do this due to various technology advances as they share a common language in speaking.

In the rest of the world, English is a foreign language. That is, it is taught in schools, often widely, but it does not play an essential role in national or social life. The teaching of modern languages in schools has an educational function, and the older learner who deliberately sets out to learn English has a clear instrumental intention whether the intention of visiting an English-speaking countries or being able to communicate and read anything in English words. Broughton (2003) states that learners of English as a foreign language (EFL) have a choice of language variety to a larger extent than second language learners. The choice of variety is partly influenced by the availability of teachers, partly by geographical location and political influence.

He also states that in the classroom context, it is described that English language teaching goes on and it is clearly part of the professionalism of a teacher of English it is described that English language teaching goes on and it is clearly part of the professionalism of a teacher of English to foreigners to be aware of the context in which he is working and how his teaching fits into the scheme of things. However, for most teachers the primary focus of attention is in the classroom, what actually happens there, what kinds of personal encounter occur there and especially what part of teachers themselves play there in facilitating the learning of the language.

As a lingua franca, English is a means of communication that is spoken widely and globally by people that have different first languages. Education for specific professional area seems predestined to be offered in English, it is by no means the only area offering such education. Specifically, tertiary education in general is clearly moving towards 'Englishization' (Phillipson, 2006), in response to the steady increase in educational mobility and the rising numbers of international students at some international tertiary institutions.

This development presupposes the relevant language competence used to entail proficiency in the respective lingua franca. However, things have changed. In an attempt not to lose international students, and the financial support and kudos that come with them, language competence in the diverse national languages is no longer usual issue. Reflecting the more recent trends towards 'elite bilingualism' (de Mejia, 
2002), English has become the 'additional' language (Fishman, Cooper and Conrad, 1977) that is presupposed at tertiary level and functions increasingly as the lecturers' and students' lingua franca. In other words, English as a lingua franca (ELF) as language of tertiary education amongst multilinguals in non-English-speaking areas seems to be here to stay. In view of these developments, it could be expected that the use of ELF in education and its implications for learning as well as classroom interaction had received applied linguistic attention and interest.

Therefore, English Applied Linguistics (EAL) has in recent years become one of the major fields of specialization at the Institute of English and American Studies. Beginning with the early to mid-1990s, the institute started offering an increasingly wide range of classes in the area of applied linguistics which are sociopragmatics, sociolinguistics, discourse analysis, conversation analysis, second language acquisition, language development, etc. The general aim of the studies in English applied linguistics is to offer a theoretically well-grounded and practically oriented course of study and empirical training to students who are interested in empirically based linguistics and want to utilize their knowledge and skills in analyzing language use in context.

\section{METHODOLOGY}

The research was conducted by using qualitative descriptive design. The data of this research were the utterances of a lecturer of Teaching English as Foreign Language class of Postgraduate School State University of Medan, containing some language styles which were transcribed into the written form of the transcripts of the teaching-learning activity. The data were taken for four weeks started in November 21 2016 until December $28^{\text {th }}, 2016$. The techniques of data collection in this research were analyzing the transcripts of lecture's utterances in a classroom setting. It was used to know types of language styles used by the lecturer in the classroom. The instrument of data collection was using voice recorder. It was used as the empirical basis for analyzing data since the data were in the form of the direct teaching-learning activity in the classroom. Then, they were analyzed by using interactive model proposed by Miles, Huberman and Saldana (2014) with three phases of data analysis. The phases are data reduction, data display and conclusion drawing or verification.

\section{RESULT AND DISCUSSION}

The result of the research showed that there were only three types of language style used by the lecturer in teaching students of TEFL class of Postgraduate School by using Joos' language styles theory (1967). They were formal, consultative and casual style. The most dominant language style was casual style (77.27\%), followed by formal style (11.36\%) and consultative style $(11.36 \%)$ in similar amount of use. The result of the research can be seen in table 1 .
Table 1. The Percentage of Types of Language Style Used by Lecturer in Teaching-Learning Activity

\begin{tabular}{cccc}
\hline No. & $\begin{array}{c}\text { Types of } \\
\text { Language } \\
\text { Style }\end{array}$ & Frequency & $\%$ \\
\hline $\mathbf{1}$ & Frozen & 0 & 0 \\
$\mathbf{2}$ & Formal & 20 & 11.36 \\
$\mathbf{3}$ & Consultative & 20 & 11.36 \\
$\mathbf{4}$ & Casual & 136 & 77.27 \\
$\mathbf{5}$ & Intimate & 0 & 0 \\
\hline & Total & 176 & 100.00 \\
\hline
\end{tabular}

Table 1. shows the types of language style used by lecturer dominantly were casual style $(72.27 \%)$. It means that the lecturer taught the students mostly in informal or friendly way. It was followed by formal style $(11.36 \%)$ that was meant that in some cases, the lecturer also used formal sentences in teaching the students as it was supposed to be. Then, consultative style appeared to be in the similar amount to formal style used by the lecturer $(11.36 \%)$. It means that as the lecturer taught the students, he sometimes discussed or asked some questions followed by the short responses of students.

Comparing to the findings of this research, a research conducted by Hasibuan (2015) about teachers' languages styles and its relations to gender differences, states that formal style was the dominant one used by both male and female teachers in the classroom with $61.7 \%$ and $78 \%$. It is very different to the findings of this research. Even though this research and Hasibuan's have similar topic about language style in teaching, these two researches show different evidence about language style used by lecturer and teachers in teaching. It means that one research is possible to have different result comparing to other researches with the same topic and setting.

Another research conducted by Naibaho (2014) also shows that formal style was used dominantly in Toba Batak wedding ceremony. Even though the percentage of formal style used the grooms and brides is not added, it still can be inferred that each of the grooms and brides gave congruent pattern of formal language style in wedding ceremony. It means that in wedding ceremony, the pattern of formality in speaking is dominantly used as it shows the substantial matter being spoken.

Thus, it can be stated that in some serious or formal situation, formal style of language is mostly used by the speakers, while it still has some possibilities to have different results in some different occasion.

\section{CONCLUSION AND SUGGESTION}

The conclusion drawn from the research is that only three types of language style used by the lecturer in teachinglearning activity in TEFL class of Postgraduate School State University of Medan. They were formal style, consultative style and casual style. The most dominant language style is 
casual style $(77.27 \%)$, followed by formal style $(11.36 \%)$, and consultative style $(11.36 \%)$ in similar amount of use.

Having seen the result of the study, some suggestions are offered as follows: 1) It is suggested to other researchers who are taking Language and Communication or conducting research with the relevant subject to find out types of language style used by other people in other context, setting and place; 2) It is advisable for speaker and listener to use the congruent style of language in speaking or giving responses to the interlocutor; and 3) It is suggested for lecturers and teachers to use relevant style of language in teaching or giving lecture as it indicates the quality and competence of themselves in delivering the materials to students.

\section{REFERENCES}

[1] A. Chaer, Sociolinguistics. Jakarta: Rineka Cipta, 1995.

[2] A. de Mejia, Power, Prestige, and Bilingualism: International Perspectives on Elite Bilingual Education. Clevedon, UK: Multilingual Matters, 2002.

[3] F. A. Hasibuan, "English teachers' language styles in teaching with reference to gender differences", unpublished thesis. Postgraduate Program, State University of Medan, 2015.

[4] G. Broughton et al., Teaching English as a Foreign Language. New York: Taylor \& Francis, 2003.
[5] H. D. Brown, Principles of Language Learning and Teaching. Mariston, New Jersey: Prentice-Hall, 1980.

[6] J. A. Fishman, R. L. Cooper, and A. W. Conrad, The Spread of English: The Sociology of English as an Additional Language. New York: Newbury House, 1977.

[7] L. Keller and C. Calhoun, Sociology. New York: The Mc Graw-Hill, 1997.

[8] L. Thomas and S. Wareing, Language, Society and Power: An Introduction. London: Taylor \& Francis, 1999.

[9] M. B. Miles, A. M. Huberman, and J. Saldana, Qualitative Data Analysis: A Methods Sourcebook $3^{\text {rd }}$ Edition. Thousand Oaks, CA: Sage, 2014.

[10] M. Joos, The Five Clocks. New York: Harcourt, Brace \& World, 1967.

[11] M. Oakeshott, "Education: the engagement and its frustration". Journal of Philosophy of Education 5 (1), 1971, 43-76.

[12] M. S. Findlay, Language and Communication: A Cross-Cultural Encyclopedia. California: ABC-CLIO, 1998.

[13] R. A. Naibaho, "Language style in Toba Batak wedding ceremony", unpublished thesis. Postgraduate Program, State University of Medan, 2014.

[14] R. Phillipson, "Figuring out the englishization of Europe", Reconfiguring Europe: The Contribution of English Applied linguistics. London: Equinox, and British Association for Applied Linguistics, 2006, 65-86.

[15] T. F. Nelson, "Gender Gaps: Understanding Teaching Styles between Men and Women". Retrieved from Association for Institutional Research Journal, 2007. 